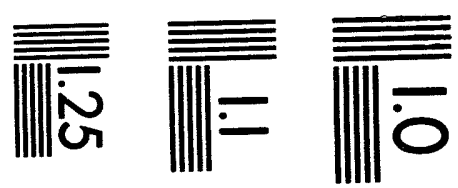

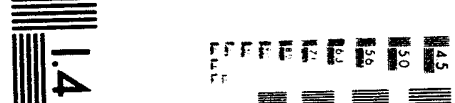

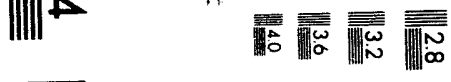

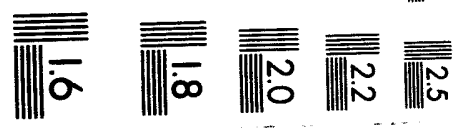



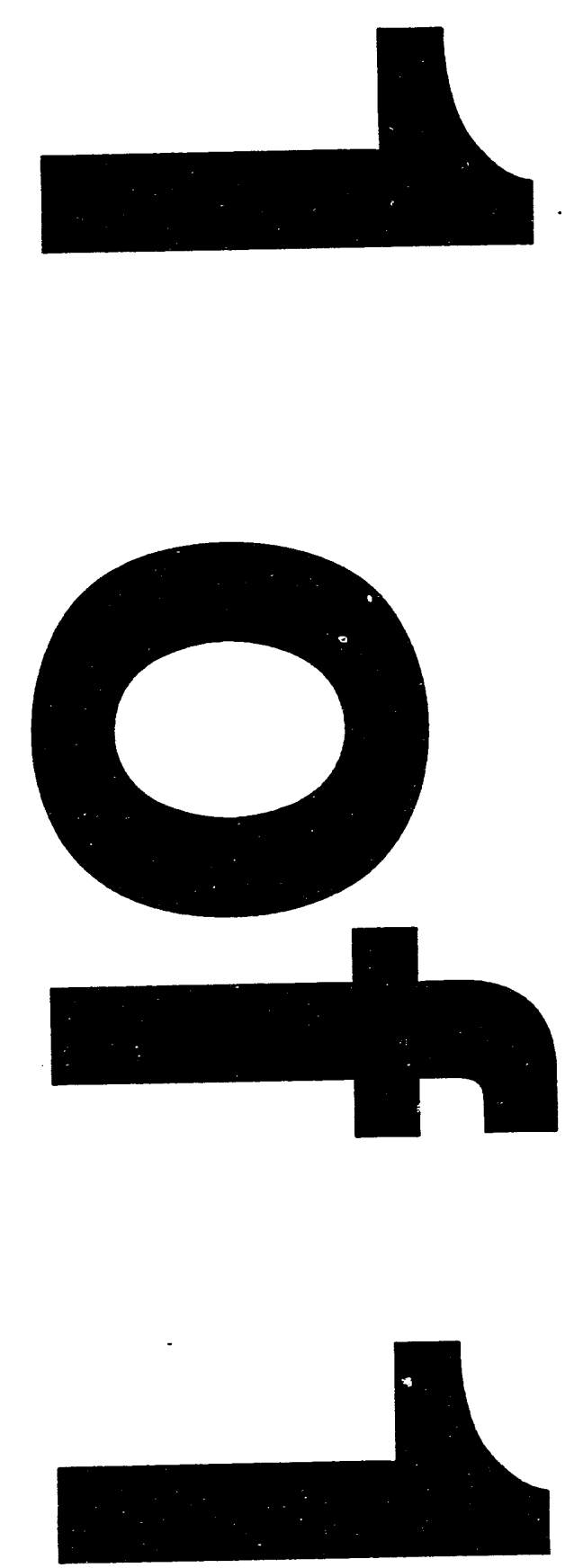


\title{
Advance Summary
}

\section{Oil and Gas Resources \\ of the Fergana Basin \\ (Uzbekistan, Tadzhikistan, and Kyrgyzstan)}

November 1993

\author{
Energy Information Administration \\ Office of Oll and Gas \\ U.S. Department of Energy \\ Washington, DC 20585
}




\section{Contacts Information}

General information regarding preparation of this Advance Summary report may be obtained from Diane W. Lique at 202/586-6090 or Craig H. Cranston at 202/586-6023, of EIA's Washington Headquarters Office. Specific information regarding the contents of the report may be obtained from the authors: Jack S. Sanders and Gary R. Long of EIA's Dallas Field Office, telephone 214/767-2200; and James W. Clarke at the U. S. Geological Survey's Reston, Virginia Headquarters, telephone 703/648-6503.

Response to this report is certainly invited, particularly any updated or different data for the Fergana basin or for other oil and gas provinces in the former Soviet Union.

\section{Diskette Information}

Reservoir-level data are available in spreadsheet files on a single computer diskette. Either a 3.5 -inch or a 5.25 -inch diameter diskette is available. The data encompass estimated and reported reservoir parameters and resulting volumetric analyses of oil and gas. Twelve separate files are stored on the diskette. One file provides introductory text, English-metric conversion units, and several engineering/geological relationships that were used. Eleven files provide basic information, parameter values for reservoirs and oil and gas, and estimated oil and gas quantities. Both English and metric unit values are included. The one text file is in ASCII format. The eleven spreadsheet files are in LOTUS *.WK1 format. There is no charge for the limited quantities of this diskette. Feedback from the user to the authors would be helpful for future electronic data products of this type.

The diskette, labeled "Fergana Basin, November 1993," is available from the Dallas Field Office of the Energy Information Administration (EIA). Please contact Gary Long, telephone 214/767-2200, or fax 214/767-2204. 


\section{Advance Summary}

\section{Introduction}

The Energy Information Administration (EIA), in cooperation with the U.S. Geological Survey (USGS), has assessed 13 major petroleum producing regions outside of the United States. This series of assessments has been performed under EIA's Foreign Energy Supply Assessment Program (FESAP). The basic approach used in these assessments was to combine historical drilling, discovery, and production data with EIA reserve estimates and USGS undiscovered resource estimates. Field-level data for discovered oil were used for these previous assessments. In FESAP, supply projections through depletion were typically formulated for the country or major producing region.

Until now, EIA has not prepared an assessment of oil and gas provinces in the former Soviet Union (FSU, Figure 1). Before breakup of the Soviet Union in 1991, the Fergana basin was selected for a trial assessment of its discovered and undiscovered oil and gas. The object was to see if enough data could be collected and estimated to perform reasonable field-level estimates of oil and gas in this basin. If so, then assessments of other basins in the FSU could be considered. The objective was met and assessments of other basins can be considered. Collected data for this assessment cover discoveries through 1987.

When Uzbekistan announced its first international offering of oil and gas license blocks in August 1993, 5 of the 10 blocks offered for exploration and development were in the Fergana geologic basin. Together these blocks extend across most of the valley area of the Fergana basin. Recognizing the benefits to Western oil and gas organizations, and possibly to the republics of Uzbekistan, Tadzhikistan, and Kyrgyzstan, EIA updated its preliminary basin study. This update mainly stems from reports in 1992 and later, of the large oil well blowout at Mingbulak field. The blowout was from a deep Miocene sandstone in the central basin graben. In addition, study updates stemmed from the USGS August 1993 basin-level estimates of oil and gas resources in the FSU, as published in USGS Open-File Report 93-316. (A comparison of estimate summaries is presented in Table 1.) Bidding for the Uzbek blocks will close January 17, 1994.

\section{Basic Results}

Compared to most other oil and gas provinces in the FSU, the Fergana basin is relatively small in geographic size, and in number and size of most of its oil and gas fields. However, with recent emphasis given to the central graben as a result of the relatively large Mingbulak field, the basin's oil and gas potential has significantly increased. At least 7 additional fields to the 53 fields analyzed are known and are assumed to have been discovered after 1987.

The term "ultimate recovery " applies here only to discovered quantities of oil and gas, and not to estimates of undiscovered quantities. Typically, ultimate recovery is the sum of cumulative production and remaining discovered reserves.

Natural gas is an important regional commodity and some gas is exported from the basin. Discovered and undiscovered recoverable nonassociated gas in the basin are estimated to be about 4.780 trillion cubic feet (1.780 trillion discovered, 3 trillion undiscovered). Of the discovered quantity, about 1 trillion cubic feet are roughly estimated as remaining Proved and Probable nonassociated gas reserves. As with oil, estimates of remaining nonassociated gas reserves also rely on quantities determined as cumulative historical gas production (used, flared, or vented). Reservoir-level, field-level, or even basin-level oil or gas production histories were not obtained. Thus, additional difficulties are involved for estimating remaining reserve quantities.

The ultimate recovery of associated-dissolved natural gas in the Fergana basin is estimated to be about 0.584 trillion cubic feet. This is gas that was contained in discovered oil reservoirs, and was simplistically estimated by applying gas-oil ratios at the reservoir level. A separate estimate of undiscovered associated-dissolved gas was not prepared.

Discovered and undiscovered recoverable oil in the Fergana basin are estimated to be about 4.018 billion barrels ( 1.018 billion discovered, 3 billion undiscovered). Of the discovered quantity, about 0.653 billion barrels are estimated as remaining Proved and Probable oil reserves.

Mingbulak field, with about 0.165 billion barrels of oil estimated as recoverable from 3 overpressured reservoirs, alone accounts for about 16 percent of the basin's ultimate recoverable oil. This field, which is not being produced, also accounts for about 25 percent of the basin's remaining Proved and Probable oil reserves. One overpressured gas condensate reservoir, with estimated Proved and Probable reserves of about 344 billion cubic feet gas, was assessed for Mingbulak field. This Paleocene gas condensate reservoir contains about 19 percent of the basin's ultimate recoverable nonassociated gas reserves. Mingbulak was the site of a large oil well blowout in 1992, which focused Western explorationist's attention on the deep, Tertiary-age section in the central basin graben. 
Figure 1. Location of Fergana Basin, South-Central Asia

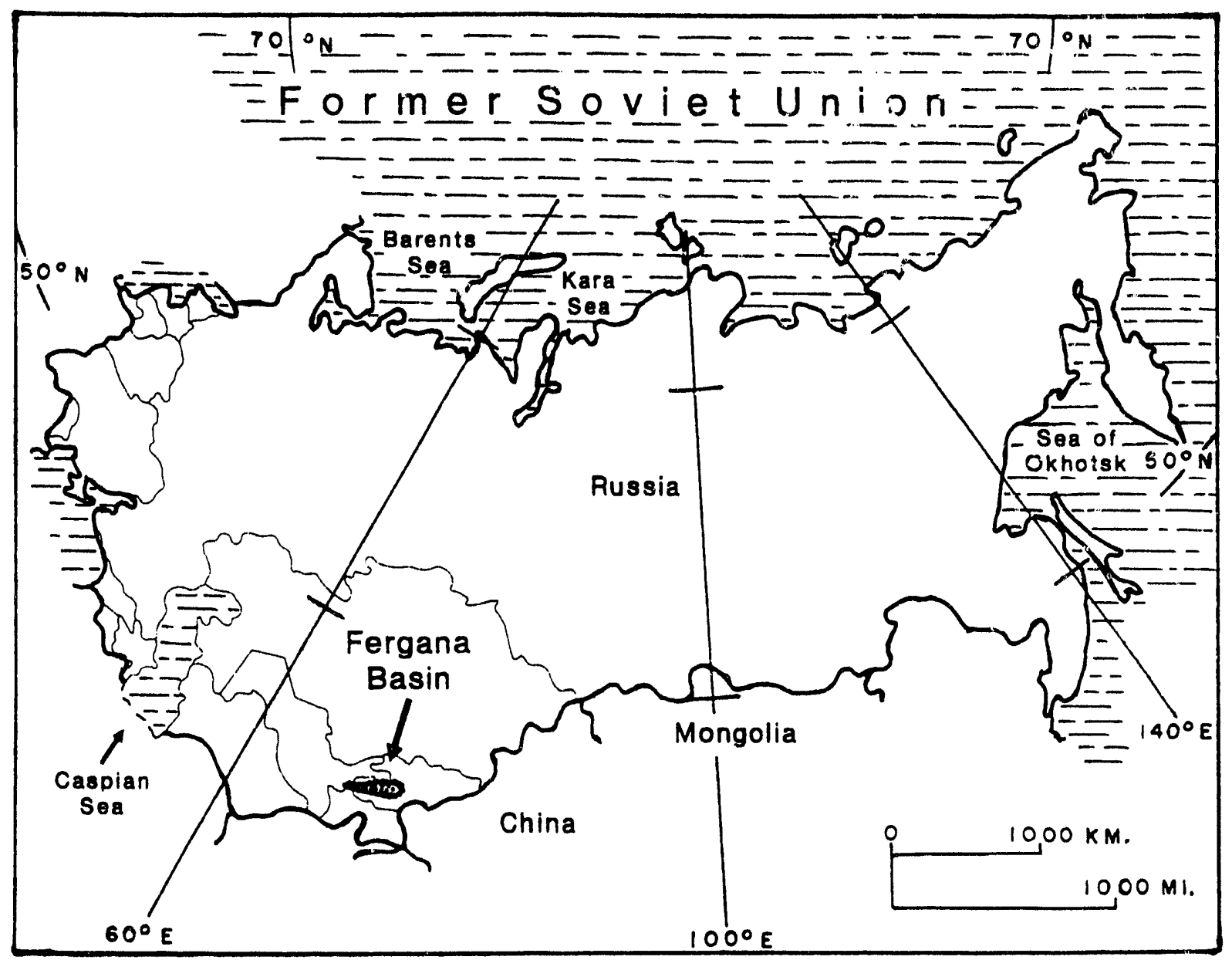

Source: Energy Information Administration, Office of Oll and aas 
Table 1. Estimate Summary and Comparison with Partial Estimates, Fergana Basin (through 1987)

\begin{tabular}{|c|c|c|c|c|c|c|c|}
\hline $\begin{array}{l}\text { Reported } \\
\text { Component }\end{array}$ & $\begin{array}{l}\text { GS Contractor, } \\
\text { Total } \\
\text { Basin } \\
\text { as of End } \\
1973 \\
\end{array}$ & $\begin{array}{c}\text { Zhabrev, } \\
17 \text { Fiolds } \\
\text { as of End } \\
1979\end{array}$ & $\begin{array}{l}\text { Moyerhoff, } \\
\text { Total } \\
\text { Bacin } \\
\text { as of End } \\
1981\end{array}$ & $\begin{array}{c}\text { Dikenshtoyn, } \\
\text { Total } \\
\text { Basin, } \\
\text { as of End } \\
\text { 1982(?) }\end{array}$ & $\begin{array}{c}\text { This EINUSGS } \\
\text { Roport, Total } \\
\text { Basin } \\
\text { ac of End } \\
1987\end{array}$ & $\begin{array}{c}\text { Potro- } \\
\text { consultante, } \\
\text { Total Basin } \\
\text { as of End } \\
1991\end{array}$ & $\begin{array}{c}\text { USGS Open-Fllo } \\
\text { Report } 83-316 \text {, } \\
\text { Total Basin } \\
\text { as of End } \\
1991 \\
\end{array}$ \\
\hline $\begin{array}{l}\text { Discovered } \\
\text { Original } \\
\text { Oil in Place } \\
\text { (million barrels) }\end{array}$ & .. & -- & -. & -- & 4,538 & -. & -- \\
\hline $\begin{array}{l}\text { Cumulative } \\
\text { Oil Production } \\
\text { (million barrels) }\end{array}$ & -- & - & 465 & 334 & 365 & $a_{392}$ & 400 \\
\hline $\begin{array}{l}\text { Discovered } \\
\text { Ultimate } \\
\text { Oil Recovery } \\
\text { (million barrels) }\end{array}$ & $b_{242}$ & 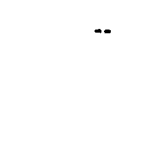 & $\cdots$ & .. & $c_{1,018}$ & 783 & 1,400 \\
\hline $\begin{array}{l}\text { Remaining Oil } \\
\text { Resen'es } \\
\text { (million barrels) }\end{array}$ & -. & $-\cdot$ &.- & 100 & $\begin{array}{l}653 \\
\text { (Proved and } \\
\text { Probable) }\end{array}$ & $\cdots$ & $\begin{array}{l}d_{1,000} \\
\text { (Identified) }\end{array}$ \\
\hline $\begin{array}{l}\text { Discovered } \\
\text { Original Non- } \\
\text { associated (NA) } \\
\text { Gas In Place } \\
\text { (billion cubic feet) }\end{array}$ & -- & -- &.- & -. & 2,403 & $\cdots$ & -. \\
\hline $\begin{array}{l}\text { Cumulative Gas } \\
\text { Production } \\
\text { (billion cubic feet) }\end{array}$ & -- & 478 & 210 & 706 & 780 & 880 & $\begin{array}{l}1,000 \\
\text { (NA gas) }\end{array}$ \\
\hline $\begin{array}{l}\text { Discovered } \\
\text { Ultimate } \\
\text { Gas Recovery } \\
\text { (billion cubic feet) }\end{array}$ & $b_{1,574}$ & $b_{987}$ & -- & $\cdots$ & $e_{2,364}$ & 1,720 & $\begin{array}{l}1,300 \\
\text { (NA gas) }\end{array}$ \\
\hline $\begin{array}{l}\text { Undiscovered } \\
\text { Recoverable Non- } \\
\text { associated (NA) Gas } \\
\text { (billion cubic feet) }\end{array}$ & -- & -. & $\cdots$ & & $\begin{array}{l}3,000 \\
(\bmod \theta)\end{array}$ & -- & $\begin{array}{l}f_{3,000} \\
(\text { mode })\end{array}$ \\
\hline $\begin{array}{l}\text { Undiscovered } \\
\text { Recoverable Oil } \\
\text { (million barrels) }\end{array}$ & - & -- & -- & $\cdots$ & $\begin{array}{l}3,000 \\
(\bmod \theta)\end{array}$ & -- & $\begin{array}{l}f_{3,000} \\
(\operatorname{mode})\end{array}$ \\
\hline
\end{tabular}

\footnotetext{
ancludes condensate production.

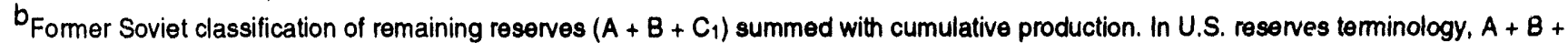
$C_{1}$ roughly equates to Proved and Probable reserves.

${ }^{c}$ Applied individual primary oil recovery efficiencies and waterflood recovery efficiencies to estimates of original oil in place, reservoir-by-reservoir. The primary recovery portion is estimated to be 927 million barrels oil; the improved recovery by waterflooding is estimated to be 91 million barrels oil. Estimates for Mingbulak field account for 165 million barrels (16.2 percent) of the basin's ultimate recoverable oil.

dUSGS "Identified" reserves approximately include economically recoverable Proved, Probable, and Possible reserves (including reserve increases by physical field growth and/or improved recovery.

${ }^{\theta}$ Applied individual gas recovery efficiencies to estimates of original gas in place for reservoir-by-reservoir sum of 1,780 billion cubic feet of nonassociated gas. Applied individual gas-oil ratios to estimates of oil recoverable by primary and waterflood mechanisms for reservoir-by-reservoir sum of 584 billion cubic feet of associated-dissolved gas. Estimates for Mingbulak field account for 574 billion cubic feet (24.3 percent) of the basin's ultimate recoverable gas (both nonassociated and associated-dissolved gas).

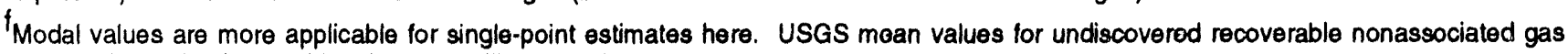
are 3,300 billion cubic feet and for oil, 4,200 million barrels.
}

Notes: Quantities are assumed to be at surface conditions. Position of values not estimated or not reported is indicated by the double dash symbol (--). Totals may not equal sum of components due to independent rounding.

Sources: Energy Information Administration, Office of Oil and Gas. James W. Clarke, retired U.S. Geological Survey, World Energy Resources Program. Other sources are identified with their estimates above. 


\section{Assessed Categories}

A world-class giant field is defined as one originally containing 500 million barrels or more of recoverable oil or equivalent gas. With an estimate of about 261 million equivalent barrels of recoverable oil, Mingbulak is not in the category of a world-class giant. However, with development of as many as 8 reservoirs, Mingbulak has the future potential of becoming a giant field. The next largest Fergana oil field size estimated is about 124 million barrels of ultimate recoverable oil, in the Sharikhan-Khodzhibad field, discovered in 1948. Mingbulak also has the largest Fergana field size for nonassociated natural gas, with about 344 billion cubic feet of ultimate recoverable gas. The next largest Fergana field size for nonassociated natural gas is about 246 billion cubic fect of ultimate recoverable gas, as estimated for the Niyazbek-Karakchikum ficld, discovered in 1974.

Under normal usage, "ultimate recoverable" oil and/or gas is the sum of cumulative production and remaining reserves, and is also referred to by some as "original recoverable reserves." Ultimate recoverable quantities presented in this report basically result from applying recovery efficiencies to volumetric estimates of original oil and gas in place, reservoir-by-reservoir. The categories of oil and gas estimated as ultimately recoverable are the nearest to original Proved plus Probable reserves in U.S. terminology, which roughly match the FSU categories of $A+B+C 1$. Simplistically, the FSU category " $\mathrm{A}$ " can be considered as reserves developed and currently being produced; " $\mathrm{B}$ " as reserves drilled and tested but not being produced; and " $\mathrm{C} 1$ " as partially evaluated but undeveloped reserves, such as that portion of a reservoir that has been delineated by exploration drilling. Also, the word "oil" as used in this report does not include condensate from gas reservoirs. No separate estimates were prepared for gas condensate, either from crude oil reservoirs, gas reservoirs, or gas condensate reservoirs.

Various counts of oil and gas reservoirs are presented in the report (such as 53 fields with an aggregate of 177 reservoirs). These counts, from various fields, do not imply that 177 reservoirs extend continuously across the basin. The use of the term "pay zone" is intended to mean extensive formational zones often containing oil and/or gas in commercial quantities. For example, some 30 pay zones are recognized within the Fergana basin, and have been locally identified by Roman numerals. Not all of these pay zones will exist in any one field, and of those that do, all may not be productive.

It is pointed out that recovery efficiency correlations and other correlations leading to estimates of original Proved plus Probable reserves stem from applications of U.S. technology, equipment, and field practices. These applications are not the same as those currently used in the Fergana basin. For example, multi-zone completions or recompletions for multiple zones in a single well are often done in the United States; these operations are understood to be seldom done in the Fergana basin. Thus, EIA estimates of ultimate recovery presented here (original Proved plus Probable reserves) may be optimistic. Contrary to this hypothesis are two different estimates for recoverable oil at Mingbulak field: (a) EIA's is about 165 million barrels for 3 reservoirs; and (b) Uzbekistan's is about 416 million barrels of "estimated reserves" for up to 8 reservoirs (57 million metric tons, Uzbek handout material of August 1993, assumed at 32.7 degrees API gravity). Some of these 8 "reservoirs" are only untested "shows" (occurrences) encountered during drilling. Additionally, for its estimates of recoverable oil in Mingbulak field, Uzbekistan has included reservoir areas that have not been delineated by drilling (the $\mathrm{C}_{2}$ reserves category of the FSU). In this assessment, $\mathrm{C}_{2}$ reservoir areas for Mingbulak field are also included by EIA in estimating Probable reserves as a special case, although only a handful of wells have been drilled near the field's anticlinal crest.

\section{Data Sources}

Published sources do not provide sufficient data for direct calculation of original oil and gas in place or recoverable quantities. Therefore, considerable estimating was necessary for many reservoir parameter values. Reservoir parameter data were needed for the simple volumetric calculation method applied. Complete historical series of annual production data were sought, but none were obtained. While no collected data were complete, the most useful suurces are listed below.

- Oil and Gas Fields of the U.S.S.R. (in Russian), edited by S.P. Maksimov, 1987.

- Gas and Gas Condensate Fields - Reference Book (in Russian), by I.P. Zhabrev, 1983.

- "Fergana Depression," in Tectonics, Formations, and Petroleum Structures (of) Border Depressions, Central Asia and Kazakhstan (in Russian), by P.V. Glumakov and others, 1988.

- Field and reservoir data from Petroconsultants, S.A., Geneva, Switzerland (primarily field cards for 19 fields, issued 1975-1977). Petroconsultants now have considerable, comprehensive, updated data, but these were not in-hand at the time of this trial analysis.

- Valuable personal communications with James R. Byrne of Byrne \& Associates, Houston, Texas, during September and October 1993.

In addition to the above listed sources, one of the EIA coauthors of this report attended the Uzbek offering of license blocks (August 25, 1993, in Houston, Texas). At this confcrence, informative presentations were heard, several personal discussions occurred, and handout materials were obtained. This information and associated contacts increased 
our understanding of the Mingbulak area and the deep Tertiary section. "Data rooms" were made available by Uzbekis$\tan$ for the use of potential bidders at the conference; therefore, the EIA representative did not enter such rooms or review those data.

\section{Basin Setting}

The Fergana basin is small, compared to other oil and gas provinces in the FSU. The basin is located in the southern portion of central Asia (Figure 1). The Fergana structural basin is an extensive, well-populated, east-west trending, intermontane basin. As shown in Figure 2, oil and gas fields extend along the basin's 186-mile length (300 kilometers). Maximum topographic relief between the valley floor and the surrounding mountain peaks is about 14,961 feet $(4,560$ meters). Boundaries of three contiguous FSU republics cross the valley. A part of Tadzhikistan occupies the western, lower end; Uzbekistan covers most of the central and eastern valley floor; and Kyrgyzstan holds the mountain flanks along the valley's northeast, east, and southern fringes. The city of Fergana is in the south-central portion of the valley, and is in the republic of Uzbekistan.

The Fergana Valley floor, with an altitude of roughly 1,500 feet (457 meters), supports agriculture, which is usually irrigated and includes cotton. Two oil refineries are located in the Fergana Valley, and together have an annual oil capacity of about 64 million barrels (8.6 million metric tons of oil). Natural gas trunk pipelines exit the valley's west end, as do railway and power transmission lines. Oil trunk pipelines do not exit the valley. A viable oil and gas infrastructure exists, but should be visited for one's own evaluation.

By the end of 1987 in the Fergana basin, about 53 relatively small oil and gas fields or field combinations had been found in all three republics, and most are located on the basin's southern flank. Also shown in Figure 2 is Mingbulak field, in the central basin graben area. Judging from review of literature, about 6 of the 53 fields reported are actually combinations of one or more originally discovered oil and gas accumulations (e.g., Chaur-Yarkutan-Chimion), but are referred to in this report as "fields". For study purposes, we chose to group these 53 fields into the following areas, based upon proximity of surface location and similarity of subsurface geclogic structure:

- North basin flank: 8 oil and 2 gas fields;

- South basin flank (northeast of Fergana): -- 12 oil and 1 gas fields;

- South basin flank (southwest of Fergana): -- 15 oil and 4 gas fields; and

- Central basin graben (designation by Glumakov, et al, 1988; actually, central and western basin): 11 oil fields, including Mingtulak, and no gas fields.
In this oil and gas field tally, a field is counted as oil if only one of its reservoirs contains oil. A field is counted as a nonassociated gas field if all of its reservoirs contain only gas or gas condensate.

\section{General Observations}

The Fergana basin is described as a compressional structural basin, with extensive high-angle reverse faults primarily on its northem flank. The latest large-scale tectonic movements occurred during Miocene-Pliocene (Neogene) time, with high-mountain growth along the basin's margin. Debris shed from these mountains resulted in a molasse of clastic materials that in the basin's center, approach a thickness of roughly 26,000 feet (8 kilometers). Most oil-gas discoveries are related to east-west trending, faulted, anticlinal traps associated with basin-margin tectonics. Fields usually contain multiple reservoirs; 177 commercial reservoirs are reported and analyzed here for the 53 fields. The matrix in Figure 3 indicates the stratigraphic and field distribution of some 30 commercial oil and gas zones from Pliocene (upper Neogene) age to Permo-Triassic age. Such multi-zone, relatively shallow distributions are attractive to explorationists.

The average estimated length and width of the reservoirs is only 3.88 by 1.04 miles ( 6.24 by 1.68 kilometers). Of the 177 reservoirs, 121 were counted as oil productive, and 56 as natural gas and gas-condensate productive. Sandstone and some limestone formations of Miocene down through Eocene age constitute the most productive and extensive pay section in the basin. This is indicated by reservoir-level data and in Figure 3 (Massaget through Alay formations). The MioceneEocene section contains about three-fourths of the basin's discovered ultimate oil recovery, whether or not Mingbulak field is included.

Depths to the top of reservoirs of the same geological age range widely. For example, a depth range for Oligocene age reservoirs, across part of the basin, is from 984 feet ( 300 meters) in the Shorsu-IV field on the southwestern Fergana basin flank to 14,764 feet (4,500 meters) in the adjacent, down-faulted, central basin graben (Varyk-Il field). The distance between these example fields, across the southern fault zone, is about 15 miles ( 24 kilometers). Such variable reservoir depths are somewhat unusual, but are attributed to vertical displacements by faulting and other structural deformation, valley flank-floor elevation differences, variable stratigraphic correlations, depositional slope environments, and the potential for incorrect reporting.

Apparently, little deep exploratory drilling has been performed in the central portion of the Fergana basin for objectives at depths approaching 19,685 feet (6,000 meters). Before the Mingbulak blowout in 1992, the deepest reported reservoir, which contained oil, was at a depth of 16,732 feet 
Figure 2. Basic Surface Features of the Fergana Basin Region, with the Five Uzbek License Blocks of 1993

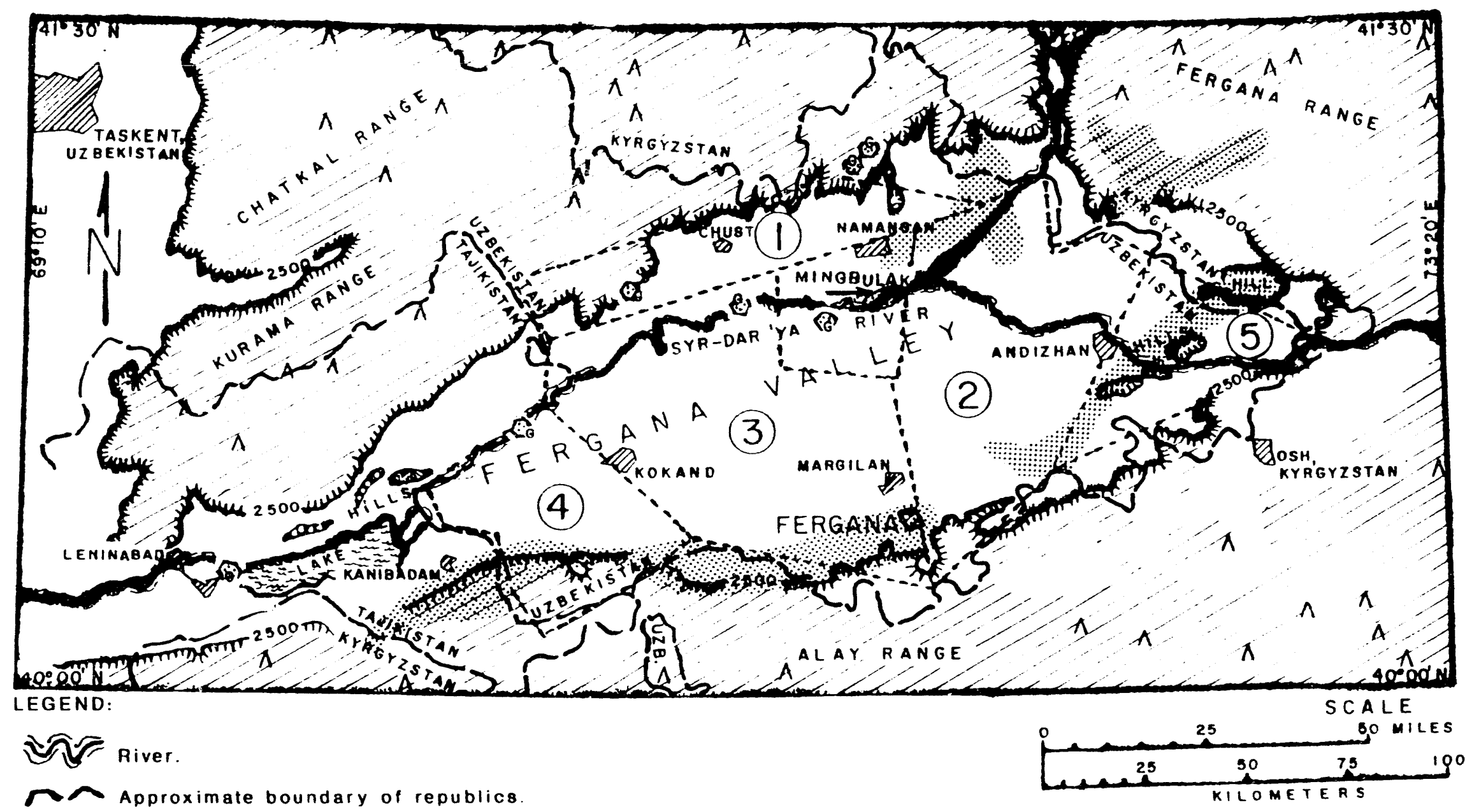

z. General trends of oll and gas flelds. So Locations of 7 scattered gas fields.

$4 y^{2}$ 2,500-foot (762-meter) topographic contour, with hatched side toward uplands $(/ / /)$.

$\wedge$ Various mountain peaks, ranging in altitude from 6,160 to 15,338 , feet $(1,878-4,675$ meters $)$.

(5) Uzbek oil and gas license blocks offered for bids on August 25, 1993, in Houston. Texas.

Source: Energy Information Administration, Office of Oll and Gas (base map from Defense Mapping Agency, ONC-F6). 
Figure 3. Pay Zone and Field Distribution of Commercial Oil and Gas in the Fergana Basin (through 1987).

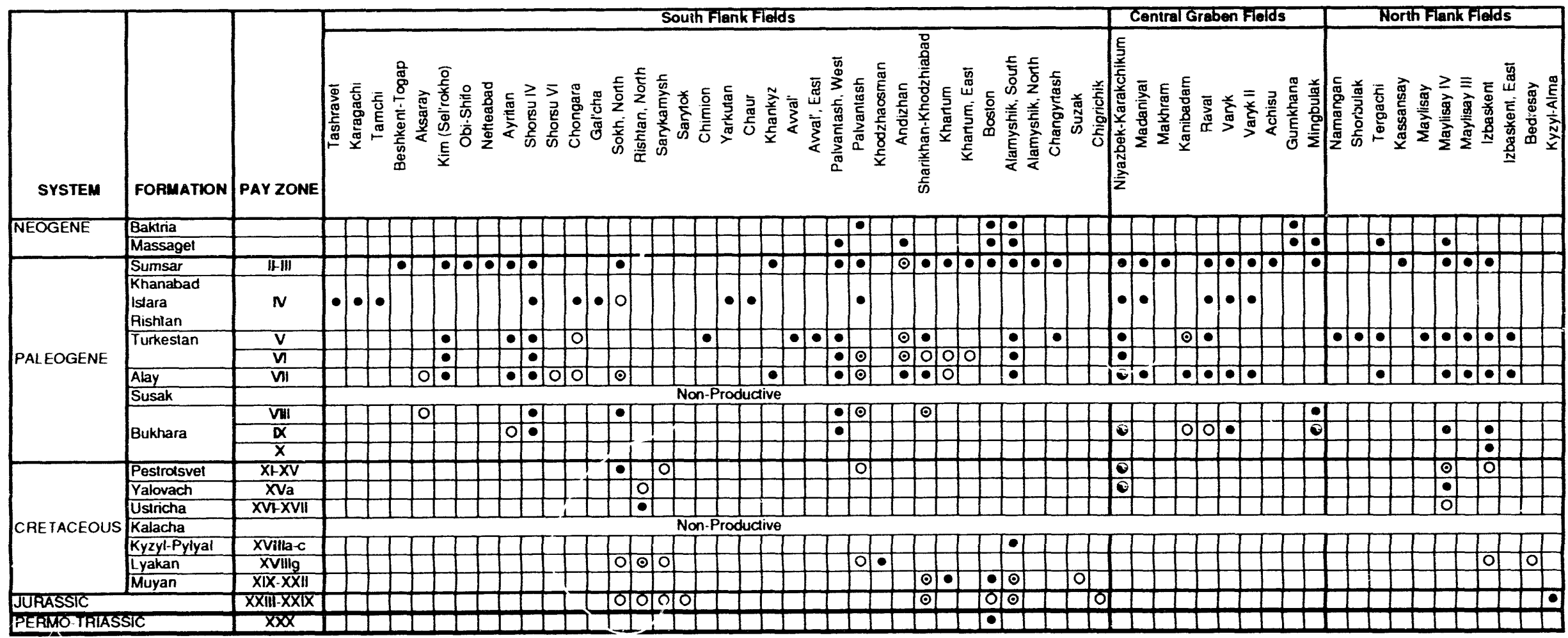

Note: At least 5 additional fields exist as noted in material presented by Uzbekistan at its license block offering (August 25, 1993, Houston, Texas): 2 other new fields are reponted

by Petroconsultants. These 7 lields mere probably discovered atter 1987. Iskoval (Uzbek block 1): Ally-Aryk, Karadzhida, Khankyz Sever-N. Rishtan Yuzh-S (Uzbek block 3),

and Sary-Kurgani, Yaipan (Uzbek block 4). Any new field additions since 1987 are unknown for Uzbek blocks 2 and 5 . The 2 Miocene (Massaget) oll reservoirs tor

Also, a Paleocene (Bukhara, Zone IX) gas condensale reservoir at Mingbulak was substituted tor an oil reservoir shown in the original Glumakov matrix.

Source: Moditied trom Glumakov and others, 1988, Ferga

Legend:

- Oil

- Oil and Gas

$\checkmark$ Condensale 
(5,100 meters). This deep pay is Eocene Zone VII, an upper carbonate of the Alay beds, found at Varyk-II field located in the western part of the valley, and on a flank of the central basin graben.

While there are exceptions, reservoirs in the Fergana basin are generally of limited areal extent, with an average of only 2,031 acres ( 8.219 square kilometers). In contrast, the average net pay thicknesses of individual reservoirs are good, with the basin average being about 30 feet ( 9.1 meters). The average reservoir porosities are generally attractive throughout the geologic section, with the average reservoir porosity for the basin being about 16 percent. The reasons for average values reflecting small reservoir areas with thick pays may be more a function of inaccuracies in available data, rather than resulting from geologic controls. However, the structural deformation and depositional environment in this basin can contribute to the types of traps indicated by these basic reservoir parameters. Exploration and development in intermontane basins commonly begin along the flanks. Relatively shallow accumulations of oil and gas along such basin flanks often are a result of migration from deeper sources.

As previously indicated, many fields contain multiple reservoirs. The reservoir-to-field ratio for the entire Fergana basin is about 3.3 ( 177 reservoirs divided by 53 fields). This simple statistic, coupled with an average reservoir depth of 6,182 feet (1,884 meters), points to some of the reasons for past exploration drilling successes. That is, more than one target reservoir was well within the depth capability of available drilling rigs.

\section{Discovery History}

Data were not obtained to analyze the history of exploratory well drilling in the Fergana basin. Periods of more or less exploration intensity are unknown, but can be inferred from the discovery history (Table 2). A question-mark symbol (?) follows field discovery years for those years inferred, rather than reported. The discovery history relies on estimates of recoverable oil and gas related to a field's year of discovery.

Table 2 presents a history of field discoveries from 1901 at Maylisay field, through 1987(?) at Bedresay field. Field sizes represent total ultimate recoveries for a field's reservoirs in categories of oil, associated-dissolved gas, and nonassociated gas. This tabulation indicates sporadic oil exploration results with a broad primary peak during the 1943-1957 period. With the exception of additional discoveries in Mingbulak field, declining results for oil exploration are evident after 1978, when Tergachi field was found.

Figures 4 and 5 are plots of curnulative oil and nonassociated gas discoveries, using data shown in Table 2. For these data plots, ultimate recoveries from each of that field's oil and gas reservoirs are assigned to the field's discovery year. Thus, quantities from any gas reservoir in an oil field are incor- porated in Figure 5's plot of cumulative discoveries of nonassociated gas. Figures $\mathbf{4}$ and $\mathbf{5}$ show periods of exploration activity/success (steeper curve slopes) and periods less successful or less active (more gradual curve slopes). Oil exploratory success in the Fergana basin became more moderate with time, after successes in the early-year period (19011957). Exceptions are a 1974-1978 secondary peak and renewed oil discoveries in Mingbulak field.

The history of nonassociated gas reservoir discoveries in Table 2 is listed from year 1935 at Andizhan field, through 1987(?) at Bedresay field. Sporadic discoveries of nonassociated gas are listed with the larger reservoirs found from about 1948 through 1974, and later at Mingbulak field (1983). The plot of cumulative discoveries of nonassociated gas (Figure 5) shows a somewhat similar pattern to that for oil (Figure 4). Typically, for an oil and gas province, there is a general decline in the size of discoveries with time. However, neither of the Figure 4 nor Figure 5 plots for oil nor nonassociated gas indicate that important discoveries in the Fergana basin are ending. Rather, the somewhat erratic discovery history and potential for more targets in the central and deeper parts of the basin both point to a potential for renewed discoveries. This potential will likely be determined by the capability to target, drill, and complete relatively decp wells.

\section{Potential of Mingbulak Area}

Estimates of the potential for oil recovery in the Fergana basin were substantially increased after March 2, 1992, when Mingbulak's well number 5 blew out and caught fire. Uncontrolled flows from this well continued for about 2 months, at reported rates from about 35,000 to 150,000 barrels of oil per day $(4,869$ to 20,869 metric tons per day at a reported oil density of 30.2 degrees API gravity). In any event, over 2 million barrels of oil $(278,252$ metric tons) were diked by emergency earthworks before the hole naturally stopped flowing. Apparently, flow ceased because a bridge formed in the hole; other explanations are also possible. The blowout reportedly came from a thick (125 feet, or 38 meters of net pay) Miocene sandstone at a depth of about 17,182 feet $(5,237$ meters).

Previously, Glumakov and others (1988, as listed in the Data Sources section) reported commercial oil in a deeper Paleocene reservoir (Zone IX) at Mingbulak. On August 25, 1993, 5 oil reservoirs were reported for Mingbulak's Pliocene-Miocene (Neogene) section and 3 additional oil reservoirs for the Oligocene-Paleocene (Paleogene) section. At this time, estimates of recoverable oil and gas are made here for only 3 oil reservoirs and 1 gas condensate reservoir, all of Tertiary (Neogene-Paleogene) age. These estimates arc under the Proved plus Probable reserves categories. Besides well number 5 , the 3 previous Mingbulak wells are reported to have experienced problems with high pressures. In 
Table 2. Fleld-Size Distrlbution by Year of Discovery, in Terms of Ultimate Recovery, Fergana Basin (through 1987)

\begin{tabular}{|c|c|c|c|c|c|c|}
\hline $\begin{array}{c}\text { Year } \\
\text { of } \\
\text { Discovery }\end{array}$ & Fleld Name & $\begin{array}{c}\text { Oll } \\
\text { (MMbbl) }\end{array}$ & $\begin{array}{l}\text { Assoolated- } \\
\text { Dissolved Gas: } \\
\text { (BCf) }\end{array}$ & $\begin{array}{l}\text { Non- } \\
\text { assoclated Gas } \\
\text { (Bef) }\end{array}$ & $\begin{array}{c}\text { Total } \\
\text { Natural Ges } \\
\text { (Bef) }\end{array}$ & $\begin{array}{l}\text { Total Barrels } \\
\text { Oll Equivalone } \\
\text { (MMbbl) }\end{array}$ \\
\hline 1901 & Maylisay & 1.943 & 0.360 & 0.000 & 0.360 & 2.003 \\
\hline 1904 & Chaur-Yarkutan-Chimion & 17.581 & 1.448 & 0.000 & 1.448 & 17.822 \\
\hline 1908 & Kim (Sel'rokho) & 77.928 & 18.140 & 0.000 & 18.140 & 80.951 \\
\hline 1927 & Shorsu IV & 9.959 & 1.881 & 0.000 & 1.881 & 10.273 \\
\hline 1932 & Changyrtash & 13.292 & 4.272 & 0.000 & 4.272 & 14.004 \\
\hline 1933 & Nefteabad & 3.536 & 0.725 & 0.000 & 0.725 & 3.657 \\
\hline 1935 & Andizhan & 7.163 & 3.314 & 4.435 & 7.749 & 8.454 \\
\hline 1943 & Palvantash & 20.008 & 0.967 & 14.906 & 15.873 & 22.654 \\
\hline 1945 & Alamyshik, Yuzh.(S) & 44.824 & 9.441 & 0.000 & $\mathbf{8 . 4 4 1}$ & 46.397 \\
\hline 1948 & Maylisu IV-Izbaskent, Vost. (E) & 68.865 & 21.284 & 150.925 & 172.209 & 97.566 \\
\hline 1948 & Sharikhan-Khodzhiabad & 124.403 & 61.636 & 5.622 & 67.258 & 135.613 \\
\hline 1949 & Chongara-Gal'cha & 33.841 & 34.993 & 51.748 & 86.741 & 48.298 \\
\hline 1952 & Boston & 30.525 & 6.871 & 15.288 & 22.159 & 34.218 \\
\hline 1954 & Avval', Vost. (E) & 2.197 & 0.419 & 0.000 & 0.419 & 2.266 \\
\hline 1954 & Rishtan, Sever. (N) & 3.575 & 1.023 & 52.918 & 53.941 & 12.565 \\
\hline 1955 & Avval' & 6.505 & 1.450 & 0.000 & 1.450 & 6.747 \\
\hline 1955 & Palvantash, Zap. (W) & 41.354 & 6.465 & 0.000 & 6.465 & 42.431 \\
\hline 1955 & Sarykamysh & 0.000 & 0.000 & 25.829 & 25.829 & 4.305 \\
\hline 1956 & Khodzhaosman & 0.823 & 0.221 & 0.000 & 0.221 & 0.860 \\
\hline 1956 & Sokh, Sever. (N) & 25.581 & 6.813 & 134.486 & 141.299 & 49.131 \\
\hline 1957 & Khankyz & 17.356 & 0.851 & 40.898 & 41.749 & 24.314 \\
\hline 1957 & Khartum & 5.641 & 3.811 & 5.448 & 9.259 & 7.184 \\
\hline 1959 & Namangan & 1.857 & 1.559 & 0.000 & 1.559 & 2.117 \\
\hline 1961 & Ravat & 22.798 & 22.003 & 29.480 & 51.484 & 31.378 \\
\hline 1962 & Maylisu III & 6.443 & 3.714 & 144.469 & 148.183 & 31.140 \\
\hline 1963 & Sarytok & 0.000 & 0.000 & 3.672 & 3.672 & 0.612 \\
\hline 1966 & Kanibadam & 1.977 & 0.852 & 38.749 & 39.601 & 8.577 \\
\hline 1966 & Kyzyl-Alma & 0.000 & 0.000 & 40.645 & 40.645 & 6.774 \\
\hline 1967 & Ayritan & 3.692 & 0.932 & 13.039 & 13.972 & 6.021 \\
\hline 1969 & Suzak & 0.000 & 0.000 & 171.913 & 171.913 & 28.652 \\
\hline 1970 & Kanabadam, Sever. (N) & 2.695 & 1.356 & 0.000 & 1.356 & 2.921 \\
\hline 1971 & Varyk & 19.612 & 12.430 & 20.498 & 32.928 & 25.100 \\
\hline 1972 & Izbaskent & 5.882 & 2.198 & 143.332 & 145.530 & 30.137 \\
\hline 1973 & Alamyshik, Sever. (N) & 10.432 & 4.861 & 0.000 & 4.861 & 11.243 \\
\hline 1973 & Shorbulak & 3.537 & 2.936 & 0.000 & 2.936 & 4.027 \\
\hline 1974 & Karagachi-Tamchi & 53.538 & 33.614 & 0.000 & 33.614 & 59.141 \\
\hline 1974 & Niyazbek-Karakchikum & 18.550 & 10290 & 245.824 & 256.113 & 61.236 \\
\hline 1976 & Beshkent-Togap & 7.808 & 0.764 & 0.000 & 0.764 & 7.936 \\
\hline 1976 & Chigirchik & 27.554 & 1.996 & 0.000 & 1.996 & 27.886 \\
\hline 1976 & Gumkhana & 19.933 & 21.324 & 0.000 & 21.324 & 23.487 \\
\hline 1978 & Madaniyat & 16.000 & 7.030 & 0.000 & 7.030 & 17.171 \\
\hline 1978 & Tergachi & 39.410 & 22.786 & 0.000 & 22.786 & 43.207 \\
\hline 1978 & Varyk II & 5.440 & 3.760 & 0.000 & 3.760 & 6.067 \\
\hline 1979 & Achisu & 3.452 & 1.473 & 0.000 & 1.473 & 3.697 \\
\hline $1982 ?$ & Obi-Shifo & 4.185 & 0.804 & 0.000 & 0.804 & 4.318 \\
\hline 1983 & Mingbulak & 164.869 & 230.098 & 343.852 & 573.950 & 260.527 \\
\hline $1983 ?$ & Tasravet & 2.865 & 0.810 & 0.000 & 0.810 & 3.000 \\
\hline 1984 & Khartum, Vost. (E) & 8.227 & 4.193 & 33.625 & 37.818 & 14.530 \\
\hline $1985 ?$ & Aksaray & 0.000 & 0.000 & 8.752 & 8.752 & 1.459 \\
\hline $1985 ?$ & Makhram & 1.911 & 0.906 & 0.000 & 0.906 & 2.062 \\
\hline $1986 ?$ & Kassansay & 8.177 & 4.542 & 0.000 & 4.542 & 8.934 \\
\hline $1986 ?$ & Shorsu VI & 0.000 & 0.000 & 8.973 & 8.973 & 1.496 \\
\hline $1987 ?$ & Bedresay & 0.000 & 0.000 & 31.118 & 31.118 & 5.186 \\
\hline Totals: & 53 fields & $1,017.743$ & 583.620 & $1,780.444$ & $2,364.065$ & $1,411.754$ \\
\hline
\end{tabular}

Notes: $\mathrm{MMbbl}=$ million U.S. barrels oil. Bcf = billion cubic feet gas. Ultimate recoveries are represented by the products of estimated original quantities in place and their respective estimated recovery efficiencies. "Reserves" are considered nearest to the U.S. reserve categories of Proved plus Probable, which are roughly equivalent to the former Soviet Union categories of $A+B+C_{1}$. Based on approximate heat contents for barrels oil equivalent (BOE), 6,000 cubic feet gas roughly equals 1 barrel oil. As surmised from the Uzbek presentation of August 25, 1993, and from Petroconsultants, at least 7 additional fields exist and probably were discovered after 1987. Question-marks (?) by field discovery years indicate inferred years, rather than reported years. Totals may not equal sum of components due to independent rounding

Source: Energy Information Administration, Office of Oil and Gas. 
Figure 4. Cumulative Discovery of UItimate Recoverable Oil, Fergana Basin (through 1987)

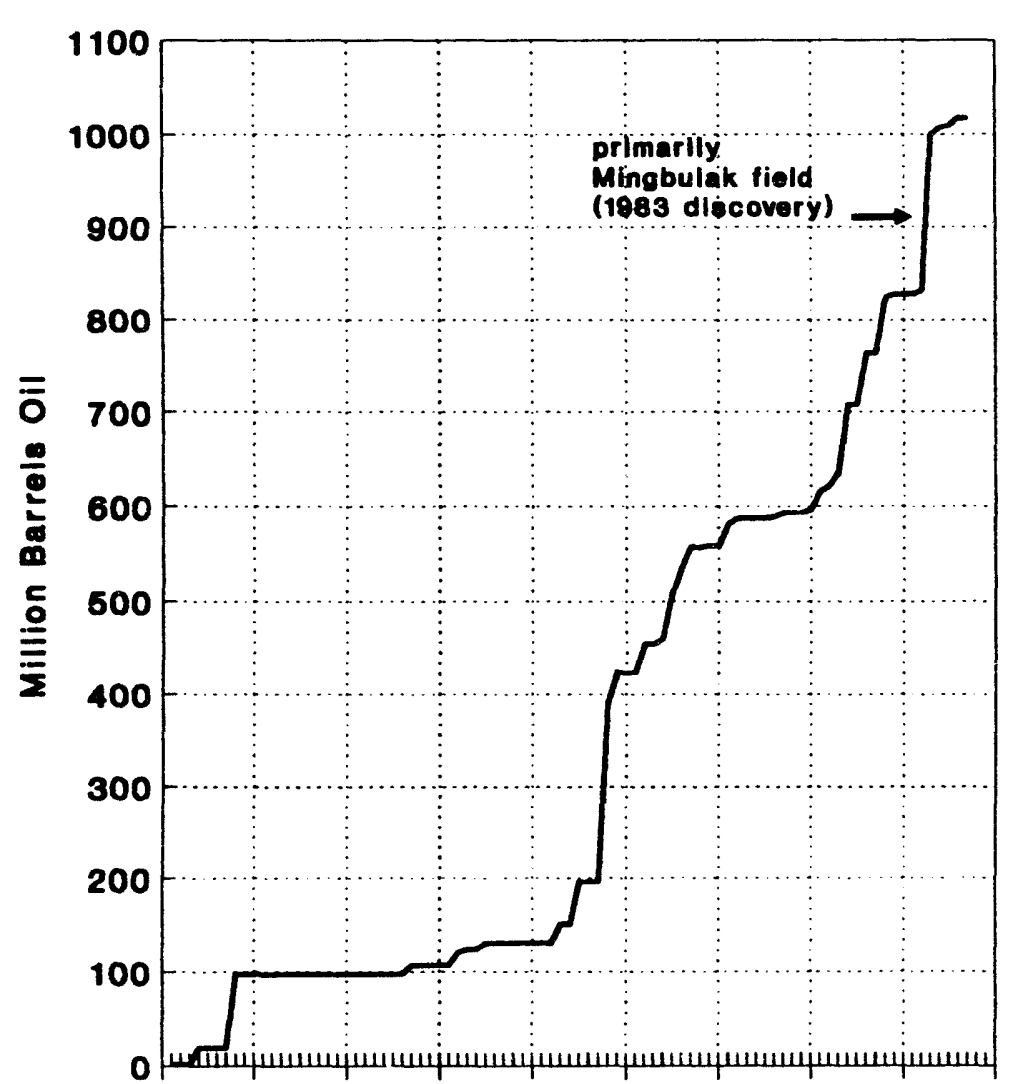

1900191019201930194019501960197019801990

\section{Year of Discovery}

Source: Table 2 and accompanying computer diekette.

Energy Information Administration, Office of Oil and Gas.
Figure 5. Cumulative Discovery of Ultimate Recoverable Nonassoclated (NA) Gas. Fergana Basin (through 1987)
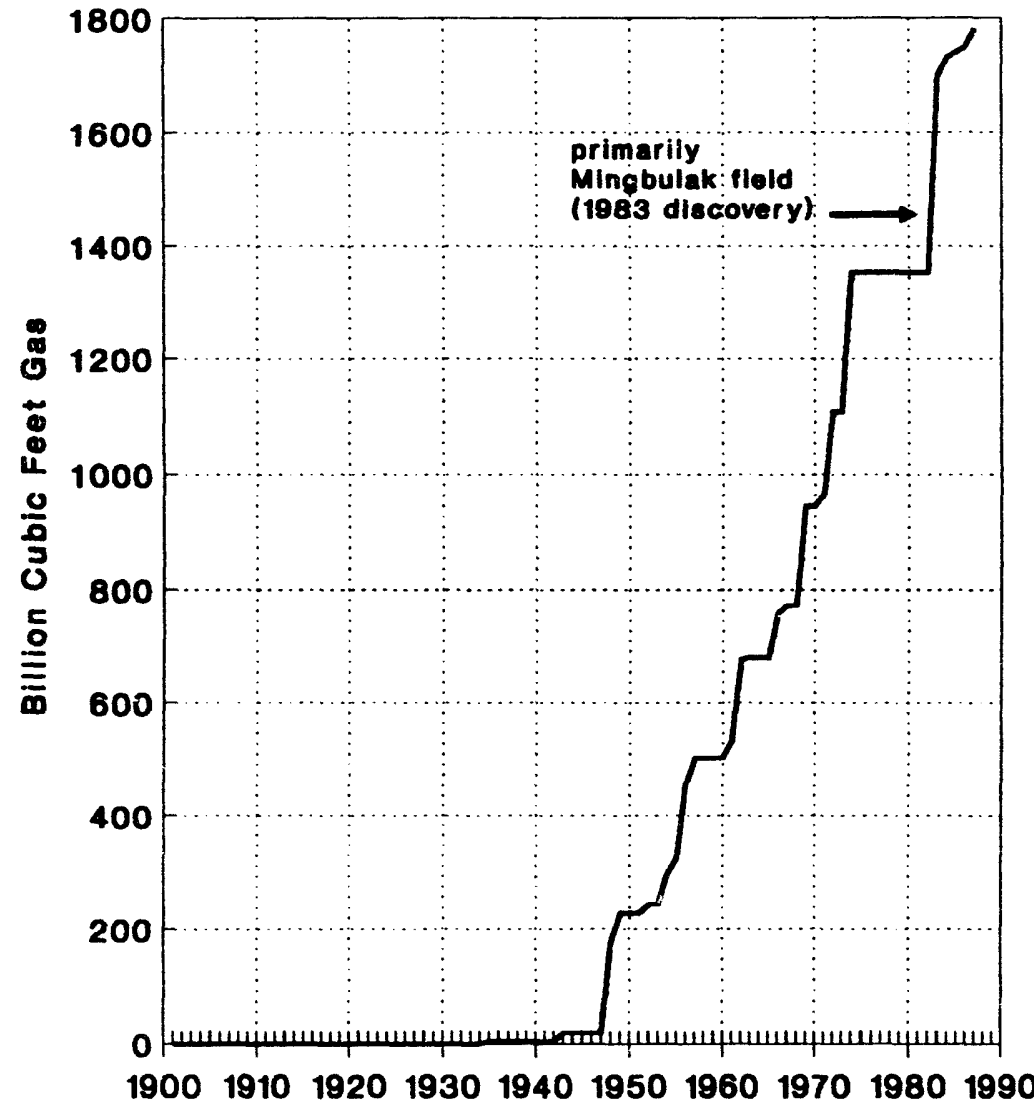

Year of Discovery

Source: Table 2 and accompanying computer dlekette, Energy Information Adminlatration, Offlce of Oll and Gas. 
Mingbulak well number 3, the first Miocene (Neogene) oil reservoir was found at 17,208 feet or 5,245 meters deep. This well was flow tested at auudt 5,749 barrels oil per day (using an oil density of 30.2 degrees API, or 800 metric tons per day with an estimated specific gravity of 0.8752 grams per milliliter). Other flow tests in well number 3 ranged down in the Tertiary (Neogene-Palesgene) section to a depth of about 19,393 feet (5,911 meters). Lesser oil flows were tested at interval tops of about 18,340 and 19,226 feet deep $(5,590$ and 5,860 meters, respectiveiy). Those lower oil tests are reported to range up to about 494 barrels of oil per day with an oil density of 42 degrees API (64 metric tons per day with an estimated specific gravity of 0.815 grams per millier). Gas and gas condensate were flow tested at an interval top of about 19,354 feet (5,899 meters) deep, from Paleocene Zone IX. The Zone IX flow test in well number 3 was reported to range up to about 7 million cubic feet of gas per day ( 200 thousand cubic meters gas, and 55 metric tons of condensate per day). Oil and gas have yet to be successfully produced from Mingbulak field.

Pressures variously reported for Mingbulak reservoirs in well number 3 range from 15,597 younds per square inch (108 million pascals) at 19,354 feet (5,899 meters) deep to 18,375 pounds per square inch ( 127 million pascals) at about 17,208 feet $(5,245$ meters) deep. (This unexplained reduction in pressure with increasing depth may be related to data inaccuracies). Pressure gradients for such pressures respectively range from about 0.806 to 1.068 pounds per square inch per foot depth; these are near to twice "normal" pressure gradients ( 0.433 pounds per square inch per foot depth). Other overpressured reservoirs in the Fergana basin are at Gumkhana field, south-southeast across the valley from Mingbulak. At Gumkhana, pressures of about 10,290 pounds per square inch (71 million pascals) are reported at depths of about 11,811 feet (3,600 meters). With the severe overpressure situation at Mingbulak, one should consider probable closing effects on the permeability system when reservoir pressures are reduced by production.

For the Fergana basin, relatively high gas-oil ratios were estimated for both Mingbulak and Gumkhana fields (at roughly 1,300 cubic feet gas per barrel oil). Selection of lower values than those used in this assessment, for gas-oil ratios and therefore, for lower oil formation volume factors, would readily cause oil and gas volumetric estimates to change. If so applied to Mingbulak oil reservoirs, for example, estimates of recoverable oil would increase and estimates of recoverable, associated-dissolved gas would decrease.

Obviously, special well drilling and completion equipment, fluids, and techniques are needed to exploit the Mingbulak reservoirs; this would be expensive work. Well number 5 is reported to have taken about 2 years to drill. As example contributors to "slow" drilling, it is understood that: (a) drilling of a well in the Fergana basin does not proceed continuously; and (b) large-diameter drilling bits at Mingbulak were used down to near the total depths for wells number 3 and 5. Four additional Mingbulak wells, with their locations generally aligned east-west, are reported as currently being drilled.

Mingbulak's structure is presented as a fairly broad anticlinal feature, with about 19,768 acres (80 square kilometers) of what is considered to be seismic, structural closure. Relief of this structural closure was separately reported to be about 1,148 feet ( 350 meters). This anticlinal feature is expected to be faulted and may have separate fault-block reservoirs. For Mingbulak's Miocene reservoirs in this assessment ( 3 oil, 1 gas condensate), about 8,000 acres were estimated as productive. This area was based on structural closure and the lowest known occurrence of oil. This feature has "stacked" (multihorizon) reservoirs in the Tertiary section, potentially in the underlying Cretaceous section, and possibly in the Jurassic section. At these depths (and temperatures), any Cretaceous or Jurassic reservoirs at Mingbulak field are expected to be gaseous. One contact at the Uzbek conference in August 1993 , indicated that the aggregate net pay of stacked Tertiary reservoirs in the Mingbulak structure was about 984 feet $(300$ meters). Also revealed at this conference, was the interesting seismic identification of 22 other deep traps in the central basin graben that are similar to Mingbulak. Structural closure on these features, which are probably anticlinal, is from about 9,884 to 24,711 acres (40 to 100 square kilometers). Three of these seismic features are reported as currently being drilled; previous drilling attempts to reach these structures have not been successful.

As aptly noted by Heafford and Lichtman of Jebco Seismic, in the August 9, 1993, issue of the Oil and Gas Journal, "the oil window lies over a wide depth range." The article lists 25 to 30 degrees Celsius per kilometer of depth as the geothermal gradient for Uzbekistan, as applied to the Fergana basin. This equates to about 1.37 to 1.65 degrees Fahrenheit per 100 feet of depth, which is, however, not a "low" gradient. The overall geothermal gradient determined from Fergana basin subsurface temperatures in this assessment is about 1.21 degrees Fahrenheit per 100 feet of depth, plus 68 degrees Fahrenheit (22.05 degrees Celsius per kilometer, plus 20 degrees Celsius). A log-calculated geothermal gradient for Mingbulak well number 3, at 17,667 feet deep, is about 1.66 degrees Fahrenheit per 100 feet of depth (30.26 degrees Celsius per kilometer). Estimated and measured temperatures for oil reservoirs at Mingbulak are from about 287 to 320 degrees Fahrenheit. At about 300 degrees Fahrenheit, liquid hydrocarbons start to decompose; crude oil blown from Mingbulak well number 5 is indicated to be waxy. In any event, deep 
crude oil exists at Mingbulak field, and its potential extends to some other deep sections of the basin.

\section{Comparisons of Reservoir Parameters by Structural Area}

Table 3 presents a complex, but insightful, summary tabulation from some of the reservoir-level files. Other than for Mingbulak field, listed average and range values for the rest of the areas are fairly common. That is, unusual subsurface conditions are not obvious by the data arrangement presented in Table 3. For example, the difference of average reservoir depths is understandable, from reservoirs on the south basin flank (southwest of Fergana, at 3,241 feet or 988 meters), to 12,216 feet or 3,723 meters in the central graben/western basin, to 18,532 feet $(5,649$ meters) average depth at Mingbulak.

Area-to-area similarities are noted in Table 3 for "small" average reservoir areas, "thick" average net pays, "high" average porosities, "low" gas-oil ratios, and the fairly narrow ranges of estimated water saturations and oil density. Again, various similarities of estimates between the structural areas of Table 3 may be a function of data quality. Any analysis depends upon the accuracy of its data. While not all of these data are claimed to be accurate, the analysis method was consistent (except for Mingbulak and Gumkhana fields).

Among other noteworthy items in Table 3, is the fairly narrow range of estimated average primary oil recovery efficiencies. These are from 17.2 to 24.3 percent, which are unusually "high" for depositional environments envisioned for the basin.

Besides Mingbulak field, it is noted that the western/central basin graben (Glumakov, et al, 1988) has the highest average of reservoir ultimate recoveries for nonassociated gas. This structural area also has the deepest average reservoir depth (12,216 feet or 3,723 meters, notwithstanding Mingbulak). Other comparisons can be made from summary data in Table 3 or from reservoir-level data on the available diskette.

${ }^{1}$ A computer diskette containing reservoir-level data in spreadsheet form can be obtained from EIA's Dallas Field Office (telephone 214/767-2200)

\section{Comparisons of Discovered Oil and Gas by Republic Areas}

After locations of the 5 Uzbek license blocks were announced, data on fields discovered through year 1987 were sorted for these areas. The aggregate area of these 5 blocks is about 6,221 square miles or 16,112 square kilometers (Figure 2). Available data do not provide accurate field locations or their relation to republic boundaries. Nevertheless, field locations were assigned to the republics of Uzbekistan, Tadzhikistan, and Kyrgyzstan, and further assigned, to the Uzbek license blocks. Two field-combinations were estimated to cross the boundary between Uzbekistan and Kyrgyzstan (Chaur-Yarkutan-Chimion and Chongara-Gal'cha). One-half of the ultimate oil and gas recovery estimated for these field-combinations was simply assigned to each republic.

With these qualifications regarding field locations, Table 4 was prepared to show another (besides Table 3's) estimated areal distribution of oil, associated-dissolved gas, and nonassociated gas in the Fergana basin. The 5 Uzbek license blocks encompass over one-half (29 of 53) of Fergana basin oil and gas fields discovered through 1987. In terms of ultimate oil recovery, these Uzbek license blocks contain nearly one-half (48.3 percent) of Fergana basin oil discovered through 1987. Tadzhikistan has about 17 percent of the Fergana basin oil and gas fields and about 20 percent of the oil discovered through 1987. Kyrgyzstan has about 26 percent of the Fergana basin oil and gas fields and about 16 percent of the oil discovered through 1987. Mingbulak field was not included with the 5 license blocks of Uzbekistan's August 1993 solicitation for tender offers.

With an estimated 165 million barrels of ultimate oil recovery as Proved and Probable reserves, Mingbulak is the largest Fergana basin field and contains about 16 percent of the entire basin's oil discovered through 1987. As with other estimates of field discovery years, all of Mingbulak's reservoirs are assigned to the initial field discovery year (Mingbulak as 1983, when well number 3 was drilled). Mingbulak's oil blowout occurred during March and April of 1992, at well number 5. Wells number 1 and number 2 are understood to have not been drilled to their objectives. Mingbulak well numbers 4,6 , and 8 are currently being drilled as is number 222 , a twin to blowout well number 5 .

A basic point of these statistics is that the borders of Uzbekistan do not encompass all oil and gas discovered in the Fergana basin. Significant oil and gas have been discovered and are being produced in Tadzhikistan and Kyrgyzstan (over 35 percent of the discovered Fergana basin oil, in terms of ultimate recovery, through 1987). An additional observation is the potential of future large oil discoveries in the deep (below about 17,000 feet) Tertiary-age section of the central 
Table 3. Comparisons of Reservoir Parameters by Structural Area, Fergana Basin (through 1987)

\begin{tabular}{|c|c|c|c|c|c|c|}
\hline Summary Parameters & $\begin{array}{l}\text { North } \\
\text { Basin } \\
\text { Flank }\end{array}$ & $\begin{array}{l}\text { South Bas } \\
\text { Northeast } \\
\text { of Fergana }\end{array}$ & $\begin{array}{l}\text { Flank } \\
\text { Southwest } \\
\text { of Fergana }\end{array}$ & $\begin{array}{l}\text { Central } \\
\text { Basin } \\
\text { Graben }\end{array}$ & $\begin{array}{c}\text { Mingbulak } \\
\text { Field }\end{array}$ & $\begin{array}{c}\text { Entire } \\
\text { Fergana } \\
\text { Basin } \\
\end{array}$ \\
\hline $\begin{array}{l}\text { Number of Oil Reservoirs } \\
\text { and Nonassociated } \\
\text { Gas Reservoirs }\end{array}$ & $\begin{array}{l}20 \text { oil } \\
18 \text { gas }\end{array}$ & $\begin{array}{l}43 \text { oil } \\
10 \text { gas }\end{array}$ & $\begin{array}{l}32 \text { oil } \\
19 \text { gas }\end{array}$ & $\begin{array}{l}23 \text { oil } \\
8 \text { gas }\end{array}$ & $\begin{array}{c}3 \text { oil } \\
1 \text { gas }\end{array}$ & $\begin{array}{l}121 \text { oil } \\
56 \text { gas }\end{array}$ \\
\hline $\begin{array}{l}\text { Number of Sandstone (ss) } \\
\text { Reservoirs and Carbonate (cb) } \\
\text { Reservoirs }\end{array}$ & $\begin{array}{r}31 \mathrm{ss} \\
7 \mathrm{cb}\end{array}$ & $\begin{array}{l}35 \mathrm{ss} \\
18 \mathrm{cb}\end{array}$ & $\begin{array}{l}32 \mathrm{ss} \\
19 \mathrm{cb}\end{array}$ & $\begin{array}{l}21 \text { ss } \\
\text { sb }\end{array}$ & $\begin{array}{l}3 \mathrm{ss} \\
1 \mathrm{cb}\end{array}$ & $\begin{array}{r}122 \mathrm{ss} \\
55 \mathrm{cb}\end{array}$ \\
\hline $\begin{array}{l}\text { Average Reservoir } \\
\text { Depth (feet) }\end{array}$ & 6,529 & 4,301 & 3,241 & 12,216 & 18,532 & 6,182 \\
\hline $\begin{array}{l}\text { Average Oil Reservoir } \\
\text { Ultimate Recovery } \\
\text { (million barrels) }\end{array}$ & 6.806 & 7.773 & 8.442 & 4.886 & 54.956 & 8.411 \\
\hline $\begin{array}{l}\text { Average Nonassociated Gas, } \\
\text { Reservoir Ultimate Recovery } \\
\text { (billion cubic feet) }\end{array}$ & 28.360 & 25.124 & 17.911 & 41.819 & $c_{343.852}$ & 31.794 \\
\hline $\begin{array}{l}\text { Average Reservoir } \\
\text { Area (acres) }\end{array}$ & 2,485 & 955 & 2,271 & 2,150 & 8,006 & 2,031 \\
\hline $\begin{array}{l}\text { Average Reservoir } \\
\text { Net Pay (feet) }\end{array}$ & 25 & 37 & 27 & 24 & 62 & 30 \\
\hline $\begin{array}{l}\text { Average Reservoir } \\
\text { Porosity (percent) }\end{array}$ & 13.4 & 16.0 & 18.7 & 16.0 & 18.0 & 16.2 \\
\hline $\begin{array}{l}\text { Reservoir Water } \\
\text { Saturation Range } \\
\text { (percent) }\end{array}$ & $20-42$ & $22-48$ & $23-65$ & $25-43$ & 35 & $20-65$ \\
\hline $\begin{array}{l}\text { Average Oil Reservoir } \\
\text { Initial Formation Volume Factor } \\
\text { (barrels per stock tank barrel) }\end{array}$ & 1.240 & 1.187 & 1.134 & 1.329 & 1.689 & 1.221 \\
\hline $\begin{array}{l}\text { Average Oil Reservoir } \\
\text { Gas-Oil Ratio } \\
\text { (cubic feet gas per barrel oil) }\end{array}$ & 458 & 343 & 243 & 633 & 1,483 & 419 \\
\hline $\begin{array}{l}\text { Reservoir Oil } \\
\text { Density Range } \\
\text { (degrees API) }\end{array}$ & $31-43$ & $30-44$ & $26-37$ & $29-41$ & $30-42$ & $26 \cdot 44$ \\
\hline $\begin{array}{l}\text { Average Reservoir } \\
\text { Primary Oil Recovery } \\
\text { Efficiency }\end{array}$ & 23.0 & 24.3 & 17.2 & 20.3 & 16.0 & 21.2 \\
\hline
\end{tabular}

\footnotetext{
${ }^{a}$ Central basin graben fields as identified by Glumakov, et al, 1988, excluding Mingbulak field. See Figure 3.

${ }^{b}$ Applied individual oil recovery efficiencies to estimated oil in place, reservoir-by-reservoir.

COnly 1 gas condensate reservoir represents the "average" value.

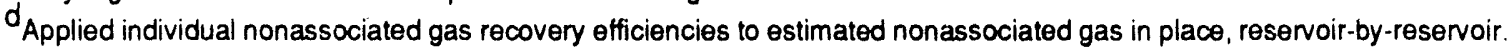
Source: Energy Information Administration, Office of Oil and Gas.
} 
Table 4. Ultimate Recovery of Discovered Oil and Gas by Republic Areas, Fergana Basin (through 1987)

\begin{tabular}{|c|c|c|c|c|c|c|c|c|c|}
\hline Item & $\begin{array}{l}\text { Uzbok } \\
\text { Blk. } 1\end{array}$ & $\begin{array}{l}\text { Uzbok } \\
\text { Blk. } 2\end{array}$ & $\begin{array}{l}\text { Uzbok } \\
\text { Blk. } 3\end{array}$ & $\begin{array}{l}\text { Uzbek } \\
\text { Blk. } 4\end{array}$ & $\begin{array}{l}\text { Uzbek } \\
\text { Blk. } 5\end{array}$ & $\begin{array}{l}\text { Mingbulak } \\
\text { Unoffered } \\
\text { Area }\end{array}$ & $\begin{array}{c}\text { Tadzhikistan } \\
\text { Areas }\end{array}$ & $\begin{array}{c}\text { Kyrgyzetan } \\
\text { Areas }\end{array}$ & $\begin{array}{l}\text { Total } \\
\text { Forgana } \\
\text { Basin }\end{array}$ \\
\hline $\begin{array}{l}\text { Number of Oil } \\
\text { and Gas Fields } \\
\text { Discovered }\end{array}$ & 4.0 & 3.0 & 4.5 & 9.5 & 8.0 & 1.0 & 9.0 & 14.0 & 53.0 \\
\hline $\begin{array}{l}\text { Ultimate Oil } \\
\text { Recovery for } \\
\text { Discovered Fields } \\
\text { (million barrels) }\end{array}$ & 52.981 & 81.295 & 39.033 & 85.741 & 232.038 & 164.869 & 200.714 & 161.073 & $1,017.743$ \\
\hline $\begin{array}{l}\text { Ultimate Assoc- } \\
\text { ciated - Dissolved } \\
\text { Gas Recovery for } \\
\text { Discovered Fields } \\
\text { (billion cubic feet) }\end{array}$ & 31.823 & 28.757 & 4.248 & 45.571 & 94.347 & 230.098 & 94.944 & 53.832 & 583.620 \\
\hline $\begin{array}{l}\text { Ultimate Non- } \\
\text { associated Gas } \\
\text { Recovery for } \\
\text { Discovered Fields } \\
\text { (billion cubic feet) }\end{array}$ & 0.000 & 14.906 & 40.898 & 198.584 & 64.418 & 343.852 & 327.093 & 790.694 & $1,780.444$ \\
\hline
\end{tabular}

Notes: "Uzbek Blk." refers to five license blocks offered by Uzbekistan on August 25, 1993, in Houston, Texas. Ultimate recoveries are the product of estimated quantities in place and their respective estimated recovery efficiencies, and are nearest to the U.S. reserves categories of Proved plus Probable. At least 7 additional fields exist as noted in material presented by Uzbekistan and by Petroconsultants. These 7 fields were probably discovered after 1987: Iskovat (block 1); Alty-Aryk, Karadzhida, Khankyz Sever-N, Rishtan Yuzh-S (block 3); and Sary-Kurgan, Yaipan (block 4). Any new field additions since 1987 are unknown for Uzbek blocks 2 and 5 . Totals may not equal sum of components due to independent rounding.

Source: Energy Information Administration, Office of Oil and Gas.

basin graben. This potential was signaled by the Mingbulak oil blowout. Previous analyses have made note of the deepbasin potential. While the 22 structures similar to Mingbulak have been identified by seismic exploration techniques, those potential structures (and reservoirs) await exploration by the drill; they are not considered to be discoveries.

Regarding the 5 blocks being offered by Uzbekistan in the Fergana basin, some simple comparisons can be made by reviewing Figure 2 and Table 4. Block 5 contains about 47 percent of oil discovered in the Uzbek offered areas, by the end of 1987. Block 5 is at the eastern end of the basin. Block 4 , nearest to the western end of the basin, contains about 62 percent of nonassociated gas that had been discovered in the Uzbek offered areas, by the end of 1987. (Various reservoirs in known fields of Block 4 and in Tadzhikistan's fields at the western end of the basin tend to be deeper and more gas-prone than typical basin reservoirs.) Uzbek Blocks 2 and 3 cross the central basin and contain a variety of relatively shallow and deep structures. Some of the deep, central graben's 22 undrilled structures mentioned at Uzbekistan's offering, implied as similar to Mingbulak, likely occur in the subsurface of Blocks 1, 2, and 3 (Figure 2). It is unknown how many of such structures have been identified in the unoffered area surrounding Mingbulak. Block 1, with only 4 fields, had about 5 percent of the basin's oil discovered through 1987 . The potential for a deep sub-thrust play has been mentioned for Block 1's elongated area along the northern basin flank.

Many comparisons of reservoir depth, porosity, geologic age, and other parameters can be obtained by making use of reservoir-level data available on the computer diskette. Reservoir-level data on this diskette are considered to be the most important part of this Advance Summary report. Again, the diskette is available from EIA's Dallas Field Office, telephone 214/767-2200. 
